\title{
On Application of TSCA to College Oral English Teaching on the Basis of Moso Teach
}

\author{
Ting Deng \\ Department of Foreign Languages \\ Sichuan Vocational and Technical College \\ Suining, Sichuan, 629000, China
}

\begin{abstract}
The research tries to combine Teacher-Student Collaborative Assessment (TSCA) with Moso Teach when assessing students' oral English. TSCA, a new assessment introduced in 2016, is a comprehensive, effective and processoriented assessment. Moso Teach is a convenient mobile teaching assistant. When applied on the basis of Moso Teach, TSCA can play a better role in improving class efficiency and enlightening class atmosphere. Besides, Moso Teach can help teachers choose appropriate samples, and guide teachers and students more accurately. This paper focuses on the necessities and procedures of applying TSCA to College oral English on the basis of Moso Teach, hoping to find a good assessment method, and to promote college oral English teaching.
\end{abstract}

Keywords-Teacher-Student Collaborative Assessment (TSCA), Moso Teach, oral English teaching, college English

\section{INTRODUCTION}

Oral English, as one of the basic skills for English learners, is very important for both teachers and students. Although many teachers and experts have tried many measures to improve oral English teaching, but there are still some problems in oral English teaching: students don't take part in oral activities actively, teachers teaching modes are tedious, the schools can't provide enough opportunities for students to apply what they get in class, and the class hours for oral English class are insufficient. In this situation, how to make best use of limited class hours, how to transform the teaching methods, how to make students participate in class actively, how to create a good atmosphere for English learning have become the main concerns for teachers and researchers.

The transform of teaching method should begin with the transform of assessment method. The traditional assessment for oral English teaching has low efficiency, incomplete and focuses too much on the result. Teacher-Students Collaborated Assessment (TSCA), an effective assessment methods, was introduced along with Production-Oriented Approach(POA) in 2016[1]. It is a comprehensive assessment, which involves both teachers and students. It evaluates the results, process, progress and the attitude of students. Every assessment is not the end of a task, but a start point for a new task, TSCA has attracted much attention of some scholars and researchers with its distinctive characteristics. But when applied to teaching practice, there are still some problems. For teachers, it is tired to calculate all the scores of students, and it is difficult to choose appropriate samples for the process of enabling. On the other hand, students may not assess the tasks seriously and carefully. With Moso Teach as an auxiliary means, it is quite convenient to solve the problems of TSCA, and also useful to improve class efficiency and students' participation in class. This research is mainly about the application of TSCA to college oral English reaching on the basis of Moso Teach.

\section{GENERAL INTRODUCTION OF TSCA AND Moso TEACH}

\section{A. General introduction of TSCA}

Based on Production-oriented Approach (POA), TeacherStudent Collaborative Assessment (TSCA) is a new assessment method which was introduced in 2016 and by Professor Wen Qiufang from Beijing Foreign Studies University. The assessment falls into three stages: before class, in class and after class. Before class, teacher needs to assess several samples in details which can be served as models for the students. In class, both teacher and students take part in the assessment, they cooperate with each other to assess several samples. After class, the students can do self-assessment and mutual assessment. The students can be further motivated and enabled in the process of assessment. There is no gap between enabling and assessment. Besides, the goal of assessment is not to give students only scores, but also to give them some comments so as to help them to be clear about their learning objectives. Therefore, assessment is actually a means of motivation.

\section{B. General introduction of Moso Teach}

Moso Teach, a mobile teaching assistant launched by Beijing Qizhi Mosoink Technology Co., Ltd. in 2014, is based on the mobile network environment and cloud service platform, using mobile intelligent devices to organize classroom teaching. Moso Teach makes it possible for timely feedback and interaction both inside and outside the classroom. Moso Teach, introduced along with the rise of "Internet plus education", integrates many functions such as information release, classroom discussion, attendance check, questioning, questionnaire survey, interactive evaluation and etc.. Moso Teach can be used as a bridge between mobile phone and classroom teaching, which makes it possible for teachers and students to interact promptly and for teachers to give students instant feedback. Moso Teach is very useful and convenient for transforming the traditional one-way teaching methods, which is in urgent need, especially for those difficult and boring classes. 


\section{THE LONG-LASTING PROBLEMS OF COLLEGE ORAL ENGLISH} TEACHING

Oral English teaching has long been a major problem in English teaching, and College students' oral English teaching has the following long-lasting questions:

Firstly, students don't take part in the class actively. Compared with the students in universities, the college students have limited vocabulary, poor tones and pronunciations. Besides, they are not confident and afraid of making mistakes. So most of them don't want to speak English in public, even not in front of the classroom. As a result, many of the students choose to be silent in oral English class.

Secondly, the traditional teaching mode is tedious. For most of the oral English class, teacher gives the topic to the students at the first beginning of the class, and then share some useful words and expression related to the topic. After that, the students are required to talk with partners or in groups about this topic. If time is permitted, some students would be invited to share their opinions about the topic, or some groups will be invited to show their group work.

Thirdly, the students in colleges lack the opportunities to apply English to their daily life. It is a common situation for college students to use English only in class, and they have few opportunities after class. Therefore, they don't have the awareness to practice their oral English. In other words, they seldom use what they get in class, which is also another reason why students can't be motivated in class.

Fourthly, the class hours for oral English teaching are not enough in colleges. Generally speaking, three-year-college students only spend 2 years in attending classes on campus, and have their internships in the third year of college. During the 2 years on campus, they need to attend many classes, including specialized courses, common courses, and other optional courses. The class hours spared for oral English teaching is too limited.

Facing the difficulties mentioned above, it is necessary for teachers and researchers to take some effective measures to maximize the teaching efficiency in oral English class. Many studies and researches demonstrate the most direct way to transform oral English teaching is to transform the assessment methods.

\section{THE NECESSITIES OF APPLYING TSCA TO COLLEGE ORAL ENGLISH TEACHING ON THE BASIS OF MOSO TEACH}

\section{A. The problems of traditional assessment}

The same with many traditional assessments, the traditional assessment for oral English has many problems as follows:

Low efficiency: For oral English test, it is quite normal for teachers to listen to each student's production task one by one and then give him or her scores according to his or her performance and the quality of production task. In order to make sure the scores are fair and appropriate, teacher may listen to the record for several times, which takes teachers much time and energy. TSCA involves all the students in assessing, which surely can reduce teachers' pressure in assessing.

Incomplete: Most of the traditional assessments only focus on the result, but not on the progress, which makes the assessments not complete and comprehensive. Nowadays, many educators and researchers in China are calling for a reform of education assessment system, and they are expecting an assessment method which focuses on both the progress and the result, which can better reflect students' key competences. It is the same situation in oral English teaching, we need a good assessment to evaluate students' language competences, their performance in class, their attitude towards the class, and the progress they make in one semester.

Result-oriented: the focus of traditional assessments is result, therefore, the traditional assessments usually end up with scores. Scores is just a measurement for students' language levels, it can't tell students shortcomings. In this situation, comments are needed for telling students what they should do to improve their oral English. The comments can motivate students for further study, which is the core principle of TSCA.

\section{B. TSCA is useful to solve the problems of traditional assessment methods}

TSCA, a new assessment method, focuses on solving the problems of traditional assessment methods, such as low efficiency, unilateral assessment, incomplete, etc.. It has been put into teaching practice since it was introduced in 2016, and has been proved a good assessment. According to a survey by Xiaoyuan Wang from Northwest A\&F University, 67.8\% of the students think they can realize their mistakes in their oral tasks after several comprehensive assessments, not only the grammatical mistakes, but also pragmatic errors and communication errors, which can help their oral expressions more standard and idiomatic. More than 70\% students think TASC can effectively solve the main problems existing in their oral presentation. All the figures show that most students are approve of the new assessment TSCA[2]. Jia He from Hehai University did some empirical studies in applying TSCA to college oral English teaching and proved TSCA can improve class efficiency, stimulate students' initiative and creativity, and improve students English competencies obviously[3]. Huijuan Xu from Guangdong University of Foreign Studies did some teaching practice in combing flipped classroom with TSCA in interpretation class and found that TSCA can save teachers from the heavy tasks in assessment and improve teaching efficiency at the same time[4]. But there are still some problems when applying TSCA in oral English teaching: there are too many calculation tasks before class, in class and after class; it is hard for teachers to choose the suitable samples; some students assess classmates' production tasks at random[5]. Therefore, we need an auxiliary means to avoid such kind of problems.

\section{Moso Teach is a good auxiliary means for TSCA}

With the rapid development of the Internet, people's daily life can't be separated from the network environment, and mobile phone has become an indispensable part for teachers 
and students. On the other hand, students like to learn new things with their mobile phones in their spare time. In this situation, why not guide students to make full use of mobile phones for mobile learning, and teachers for mobile teaching. Moso Teach, which can bring more interaction between teachers and students in classroom teaching with mobile phones as teaching media, is changing the traditional tedious teaching mode.

When combined with TSCA, Moso Teach can effectively solve some problems of TSCA. First, it is convenient. With the help of Moso Teach, students can take part in the learning activities and assessment activities conveniently before class, in class and after class. Second, it is a good guidance for teachers and students. Both scores and comments will be required when assessing a student's task. All the scores can be calculated automatically, and all the comments can tell the shortcomings of students, which could be the focuses of both teacher and students. Third, it can improve class efficiency. Most of the assessment tasks can be undertook before and after class, which can save a lot of time for class. What's more, there can be multiple learning tasks for different students with different English levels in class, and it is possible to allocate different tasks for different students at the same time, which is good for students to learn new things selectively. Forth, it can help teachers to choose appropriate samples. According to TSCA, teacher needs to choose appropriate samples before class. With the help of Moso Teach, teacher can require students to finish the first round assessment within a given time, and teacher can choose the samples according to the average scores, which would be more reliable and reasonable. Fifth, It is good to improve students' participation in class. Students' every participation before class, in class, and after class can be recorded clearly by Moso Teach, and all the records can be taken into consideration when giving students' scores for final examination. Therefore, students are surely to be more active. Finally, it is a combination of formative evaluation and summative evaluation, which takes the learning process, attitude, and the performance of students into consideration when evaluating a student. With Moso Teach, it is very easy for teachers to know the general performance of a student from the backstage supporter's data, and to warn the students if they didn't do well enough in class.

\section{The feasibility of combining TSCA and Moso Teach}

When applying Moso Teach, teachers play a leading role in guiding, inspiring and monitoring the teaching process, during which teachers are the guiders, resource providers, learning promoters, and facilitators. It is the same situation when applying TSCA. Therefore, TSCA and Moso Teach are in complete agreement on this point. Besides, both TSCA and Moso Teach have been proved good and useful for teaching, and both of them are gradually transforming the traditional assessment ways and the traditional teaching methods. At last, all the college students and teachers have a mobile intelligent phone, and the convenient network makes M-learning possible for students and M-teaching for teachers.

\section{THE PROCEDURES OF APPLYING TSCA TO COLLEGE ORAL ENGLISH TEACHING ON THE BASIS OF MOSO TEACH}

\section{A. The application before class}

With the guidance of POA, teachers should firstly make the students clear about the productive task for the new class, and it is necessary to let students try to produce their tasks so as to help them to understand their own weak points and to be clear what they need to be concentrated on in class, which lays a good foundation for selective learning in the process of enabling. Therefore, in the process of motivation, teacher can upload some learning materials in the Moso Teach, both video and non-video materials, and require all the students to learn these materials before a given deadline. The Moso Teach can record the period of time the students spend in learning these materials with a percentage. For example, student A learned $80 \%$ of the video. Student B learned $90 \%$ of the video, student C learned $100 \%$ of the video. The teacher can also require students to keep down and upload their notes, including what they have learned from the materials and what they need to learn next class. In this way, the students can be clearer about their own shortcomings and can be better motivated for the new class. It's better for teacher to upload and give his requirements two or three days before class so as to give enough time for students.

After the deadline, it comes to the assessment for motivation. There are many different ways for assessment, such as teacher's assessment, self-assessment, mutual assessment, classmates' assessment, and assessment between groups. The teacher can choose different assessment methods flexibly for different situations. The teacher needs to release the evaluation standards when uploading the motivation tasks, and can provide some assessing samples for the reference of students. In order to make the assessments more objective and accurate, the teacher can assign at least 5 assessment tasks for every student. All the assessors involved must give a score and some comments for every assessment. The scores can be a part of the final examination and the comments tell the assessed students shortcomings and mistakes. When calculating the scores, the highest and the lowest scores will be deducted, and the average scores of all the scores left will be the final score of a student. All these calculating tasks are finished by the backstage supporter of Moso Teach, which can save much time and energy for teachers. After all the students finish their assessment task, the teacher can choose some samples with different scores and analyze them carefully to find out the students' general problems. And in the process of enabling, all these problems need to be focused on so as to make the class more effectively.

\section{B. The application in class}

In the process of enabling, the students need to concentrate on improving their weak points selectively, and the productive tasks can be divided into several sub-tasks, each of them can help students get closer to the final productive task. The teacher can adopt different activities in class to activate the students, such as pair work, group work, brain storm, discussion, question and answer, and etc.. The Moso Teach can record students' performance in class comprehensively and accurately. 
In class, students can put up their hands through Moso Teach for answering questions, can take part in answering the quick responses questions, can do some pair work or group work, and can shake the mobile devices for getting a chance to answer questions. And the teacher can give the students with good answers some "likes", which can be taken into consideration when giving final evaluation. All of the data, such as how many times does a student put up his hand, how many "likes" does a student get, and how is a student's performance in the pair work or group work, can be recorded automatically by the backstage supporter of Moso Teach.

\section{The application after class}

In the process of assessment, all the students and the teacher would be involved. And the assessment begins in the process of motivation, goes through the whole class, and doesn't end at the end of class. TSCA can be divided into two kinds of assessment, namely instantaneous assessment and deferred assessment. The former one occurs immediately after the students' performance, while the latter one occurs after class, or after the class activities. Therefore, assessment doesn't stop until the scores for final examination are given.

Oral English class requires students’ participation in class, which means process evaluation, is more important than outcome evaluation. When giving students final examination scores, the teacher not only focuses on the quality of productive tasks, their language competences, but also takes students' progress, students' performance and their potentials into consideration.

\section{CONCLUSION}

TSCA is an assessment method, while Moso Teach is a teaching assistant. When combing the two, the college oral English class will have several improvements as follows: Firstly, the college oral English class will be more efficient. In the process of motivation, students can realize what they need to finish the productive task, and they can be well prepared for the class. And teachers can select appropriate samples for the process of enabling. So in the class, the teachers focus on enabling students to produce the final task, during which some sub-tasks will be given. The teachers only deal with the students' weak points exposed in the process of motivation and students pay more attention to their own weak points. Therefore, the class is efficient for both teachers and students. Secondly, the college oral English class will be processoriented. For every teaching task, the assessment begins from the process of motivation, goes through the process of enabling, and doesn't finish after the process of assessment, since the assessment is actually a new starting point for motivation. TSCA doesn't only focus on the results but also takes the process into consideration. Moso Teach can help record all the students' participation before class, in class and after class, which is a good way to make students study by themselves during the whole semester. Thirdly, the college oral English class will have a good atmosphere for language learning and teaching. The students take part in class actively; the teacher can get more teaching points effectively from students and for students, which in turn arouses students' interesting. In this way, a good circulation is formed in class, and a good atmosphere for oral English teaching and learning is created.

The research find it is useful to apply TSCA to college oral English teaching on the basis of Moso Teach by means of practical research, there should be some empirical research to find out how can this application improve students' language competencies, and it will be the further research of the author. At the same time, the author hopes more teachers, scholars, and experts do some research related to this application, so as to improve college oral English teaching

\section{ACKNOWLEDGMENT}

This article is one of the research achievements of the project research The Application of Production-oriented Approach (POA) to Teaching Oral English for English Majors in Higher Vocational Colleges (18SB0701), funded by Ministry of Education in Sichuan Province and Sichuan Vocational and Technical College.

\section{REFERENCES}

[1] Qiufang Wen, TSCA: A New Assessment Method Created Along With Production-oriented Approach [J]. Foreign Language World. October, 2016. (In Chinese)

[2] Xiaoyuan Wang, Yueli Song. The Application of TSCA Assessment Theory to College Oral English Teaching [J], Journal of Inner Mongolia Normal University (Educational Science), July, 2018(In Chinese)

[3] Jia He, Jiannan Liu. Application of TSCA to College Oral English Teaching [J], Journal of Chongqing University of Education. May, 2019. (In Chinese)

[4] Huijuan $\mathrm{Xu}$, The Practical Research on Application of TSCA to Interpretation Class [J]. English Square. July, 2018. (In Chinese)

[5] Wenjuan Qian, Application of Blended Learning Model to Public Courses in Vocational Colleges on the Basis of Moso Teach Class [J]. Vocational \& Technical Education Forum, June, 2018. (In Chinese) 